\title{
Genetic background of aggressive behaviour in dogs
}

\author{
Witold Stanisław Proskura ${ }^{1}$, Anna Frost ${ }^{1}$, Leonard Gugała ${ }^{3}$, Andrzej Dybus ${ }^{1}$, \\ Wilhelm Grzesiak ${ }^{2}$, Justyna Wawrzyniak ${ }^{1}$, Sylwia Uchman ${ }^{1}$ \\ ${ }^{1}$ West Pomeranian University of Technology, Laboratory of Molecular Cytogenetics, \\ ${ }^{2}$ Laboratory of Biostatistics, Szczecin, Poland \\ ${ }^{3}$ Small Animal Veterinary Practice, Szczecin, Poland \\ Received June 22, 2012 \\ Accepted August 28, 2013
}

\begin{abstract}
The background of aggression is very complicated and the basis of its occurrence has not been well explained yet. It is thought that tendency to aggressiveness is an effect of both environmental and genetic factors. Aggression is a very undesirable behavioural trait in dogs living with humans. The aim of this study was to determine the relationship between two polymorphisms: $D R D 4$ intron II VNTR and $\mathrm{C} / \mathrm{T}$ substitution in exon I HTR $2 B$ genes and aggressive behaviour in dogs. The VNTR polymorphism in the DRD4 gene was detected by agarose gel electrophoresis following PCR amplification, whereas $\mathrm{C} / \mathrm{T}$ substitution in the $H T R 2 B$ gene was analysed using amplification created restriction sitepolymerase chain reaction (ACRS-PCR). A total of 121 dogs of several breeds were analyzed. All animals were classified based on a veterinary interview and observation in two groups: aggressive $(\mathrm{n}=21)$ and non-aggressive $(\mathrm{n}=100)$. Significant differences in $D R D 4$ genotype frequencies between aggressive and non-aggressive dogs were observed $(P<0.05)$. The study provides a clear evidence of an association of VNTR polymorphism within intron II of the DRD4 gene with the occurrence of aggressive behaviour in dogs. Moreover, the findings give good justification for further research aimed at evaluation of the possibility of using this genetic marker in Marker-assisted Selection.
\end{abstract}

Aggression, serotonin, dopamine, Canis familiaris, receptor

Within domestic dog species, over 400 pure breeds established by selective breeding for various purposes can be recognized. Dogs of different pure breeds have characteristic traits which allow distinguishing one breed from another. The traits do not regard only their morphology but also their behaviour (Hart and Miller 1985; Houpt 2007). This fact can lead to the conclusion that some behavioural traits such as aggression may be genetically dependent. Aggression in vertebrates is a characteristic primitive behaviour that also occurred in their ancestors, so an underlying similarity of molecular mechanism may be expected (Nelson and Chiavegatto 2001). The tendency to aggressiveness seems to be a resultant of both environmental and genetics-related factors (Picciotto and Wickman 1998; Houpt 2007; Barsky 2010).

Different substance groups such as hormones, enzymes and neurotransmitters are involved in the modulation of aggressive behavior (Nelson and Chiavegatto 2001). Neurotransmitters are very important for correcting the function of the central nervous system and play a crucial role in modulating both animal and human behaviours (Våge and Ligas 2008). Some reports show association between different behaviours and genetic variability such as single nucleotide polymorphism (SNP) in the genes coding regulatory enzymes, transporters and receptors (Savitz and Ramesar 2004). Serotonin (5-hydroxytryptamine; 5-HT) is indicated as one with the highest impact among the group of several neurotransmitters linked to aggression (Nelson and Chiavegatto 2001). 5-HT is involved in many processes linked to the central nervous system such as pain, anxiety, mood, perception and especially aggression (Bradley et al. 1986). Dopamine is also a very important neurotransmitter strictly involved in the modulation of behaviour (Våge and Ligas 2008). Dopamine and its receptor antagonists e.g. haloperidol were used in

Address for correspondence:

Witold Stanisław Proskura

Laboratory of Molecular Cytogenetics

West Pomeranian University of Technology

Doktora Judyma 10, 71-466 Szczecin, Poland

Phone: +48914496806

E-mail: wproskura@zut.edu.pl

http://actavet.vfu.cz/ 
the treatment of aggressive behaviour in psychotic patients (Fitzgerald 1999). It is understandable because dopamine plays a crucial role in many related activities including aggression (Summers and Winberg 2006). Receptors for the mentioned neurotransmitters are found in the neural cells in many places in the brain. Polymorphism of the genes coding these receptors has been identified and some of the polymorphic sites are linked to human personality traits (Niimi et al. 1999). Genes coding dopamine and serotonin receptors are highly polymorphic. Våge and Lingaas (2008) have identified 34 novel SNPs in the coding regions of canine dopamine- and serotonin-related genes among which 23 SNPs were related to genes coding DRD and 5-HT receptors including the HTR2B and DRD4 genes. Within the intron II of canine DRD4 gene, VNTR polymorphism was discovered. It was primarily indicated as $17 \mathrm{bp}$ insertion/deletion. However, gene structure analysis, performed by Hejjas et al. (2009), has indicated that there are 3 repeats $(17 \mathrm{bp})$ in the longer allele and 2 repeats in the shorter allele.

The aim of this study was to establish whether there is a relationship between aggressive behaviour in dogs and two polymorphisms: $D R D 4$ gene intron II VNTR identified by Nara et al. (2005) and C/T substitution in HTR2B gene exon I identified by Våge and Lingaas (2008).

\section{Materials and Methods}

A total of 121 dogs of several breeds were analyzed. All dogs were classified in two groups: aggressive $(n=21$, dogs showing aggression toward both human and other dogs) and non-aggressive $(n=100)$. That classification was based on a veterinary interview and observation. Detailed data regarding the studied animals are given in Table 1. All analyses included in our study were performed in May and June 2010.

Table 1. Characteristics of studied animals.

\begin{tabular}{lrrrr}
\hline Breed group & & Females & Males & $\begin{array}{c}\text { Aggressive } \\
\text { females/males }\end{array}$ \\
\hline Sheepdogs & $n$ & 9 & 15 & $-/ 4$ \\
Pinscher, Schnauzer, Molossoid breeds, & 24 & & & \\
$\quad$ Swiss mountain and cattle dogs & 39 & 20 & 19 & $2 / 6$ \\
Terriers & 14 & 5 & 9 & $-1 / 1$ \\
Dachshunds & 4 & 2 & 3 & $-/-$ \\
Spitz and primitive types & 6 & 3 & 1 & $-/-$ \\
Scenthounds and related breeds & 1 & 0 & 3 & $2 / 1$ \\
Pointing dogs & 8 & 5 & 4 & $1 / 1$ \\
Retrievers, flushing dogs, water dogs & 16 & 12 & 5 & $-/ 1$ \\
Companion and toy dogs & 8 & 3 & 1 & $7 / 14$ \\
Sighthounds & 1 & 0 & 62 & \\
Total & 121 & 59 & & \\
\hline
\end{tabular}

${ }^{1}$ Breed groups according to the Fédération Cynologique Internationale (FCI)

The DNA was isolated from collected peripheral blood samples using Master Pure ${ }^{\mathrm{TM}}$ DNA Purification Kit (Epicentre Biotechnologies, Illumina, Madison, Wisconsin, USA). The VNTR polymorphism in the DRD4 gene was detected by agarose gel electrophoresis following PCR amplification, whereas C/T substitution in the HTR2B gene was analysed using amplification created restriction site-polymerase chain reaction (ACRSPCR). The primer sequences for DRD4 and $H T R 2 B$ fragments amplifications (Table 2) were designed using Primer3 software (Untergasser et al. 2007). The PCR mixture contained approximately 60 ng of genomic DNA, 10 pmol of each primer, $1 \times$ PCR buffer, $1.5 \mathrm{mM} \mathrm{MgCl} 200 \mu \mathrm{M}$ dNTP, DMSO $(10 \%), 0.4$ units Taq-polymerase (Fermentas, Thermo Scientific, St. LeonRot, Germany) and deionized water up to $15 \mu 1$. The following thermal 
Table 2. Primers used for PCR amplification of sequences containing polymorphic regions of the DRD4 and the $H T R 2 B$ genes in dogs

\begin{tabular}{|c|c|c|c|}
\hline Gene & Polymorphism site & Primers & Amplified sequences \\
\hline \multirow{3}{*}{ DRD4 } & & & $1445-1638$ \\
\hline & VNTR & F 5 `-GCCTCCATCTTCAACCTGTG-3` & (exon II-exon III) \\
\hline & Intron II & R 5'-CTGGCGGTTGTAACTCAGC-3’ & (GenBank: AY686595.1) \\
\hline \multirow{3}{*}{$H T R 2 B$} & $C / T$ substitution & F 5'-CTGGTGAGCAACAGGGAAAGAA-3' & $134-291$ \\
\hline & Exon I & R 5-CACTGCTAGGGACATTAGAAAATAATC-3: & (exon I) \\
\hline & & 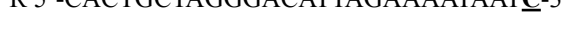 & (GenBank: AY832859.1) \\
\hline
\end{tabular}

$\mathrm{F}$ - forward, $\mathrm{R}$ - reverse

profile was applied for both $H T R 2 B$ and $D R D 4$ fragments amplification: denaturation of DNA template at $94{ }^{\circ} \mathrm{C}$ for $5 \mathrm{~min}$, followed by 36 cycles (denaturation at $95{ }^{\circ} \mathrm{C} / 30 \mathrm{~s}$, primer annealing at $60{ }^{\circ} \mathrm{C} / 45 \mathrm{~s}$, extension at $72^{\circ} \mathrm{C} / 35 \mathrm{~s}$ ) and final extension at $72^{\circ} \mathrm{C} / 5 \mathrm{~min}$. PCR products of $H T R 2 B$ were digested with TaqI enzyme (Fermentas, Thermo Scientific, St. LeonRot, Germany) at $65^{\circ} \mathrm{C} / 3 \mathrm{~h}$. The digestion products of HTR $2 B$ and PCR products of DRD4 were separated by horizontal electrophoresis in 3\% agarose gels (Prona, Southampton, UK) stained with ethidium bromide (AppliChem GmbH, Darmstadt, Germany) and visualized using UV transilluminator.

Differences between the observed frequencies of the DRD4 and HTR2B genotypes, in group of aggressive and non-aggressive dogs, were estimated using the chi-square test using the conventional $P \leq 0.05$ criterion of significance.

\section{Results}

The present study attempted to determine the relationship between two polymorphisms: DRD4 intron II VNTR and C/T substitution in exon I HTR $2 B$ genes and aggressive behavior in dogs. Two alleles for dopamine receptor gene were observed, where $P$ was a shorter allele (194 bp) and $Q$ was a longer allele $(211 \mathrm{bp})$. It resulted in occurrence of the following genotypes: $Q / Q(211 \mathrm{bp}), P / Q(211,194 \mathrm{bp})$ and $P / P(194 \mathrm{bp})$ (Plate $\mathrm{V}$, Fig. 1). For the $H T R 2 B / T a q \mathrm{I}$ polymorphism, three genotypes were obtained: $C / C$ (158 bp, no digestion), $C / T(158,130,28 \mathrm{bp})$ and $T / T(130,28 \mathrm{bp})$ (Plate V, Fig. 2).

The DRD4 intron II VNTR polymorphism was identified in both analysed groups of dogs. The $P / P$ genotype was the most frequent $(\mathrm{f}=0.572)$, followed by the heterozygotic variants $P / Q(\mathrm{f}=0.238)$, whereas the $Q / Q$ genotype was the least frequent $(\mathrm{f}=0.190)$ in the group of aggressive dogs. In the group of non-aggressive dogs $P / Q$ and $P / P$ genotypes were identified with the same frequency $(\mathrm{f}=0.290)$ whereas the $Q / Q$ genotype occurred with a frequency of 0.420. Significant differences in genotype distribution of the VNTR polymorphism in the $D R D 4$ gene between aggressive and non-aggressive dogs were observed $(P<0.05)$. Allele

Table 3. Genotype and allele frequencies for the dopamine D4 receptor and serotonin receptor 2B genes.

\begin{tabular}{|c|c|c|c|c|c|c|c|c|}
\hline Polymorphism & Group & $\mathrm{n}$ & $\begin{array}{c}\text { Genotype } \\
Q / Q\end{array}$ & $P / Q$ & $P / P$ & $\begin{array}{c}\text { Allele } \\
Q\end{array}$ & $P$ & $\chi^{2}$ statistics \\
\hline \multirow{4}{*}{$\begin{array}{l}\text { DRD4 VNTR } \\
\text { Intron II }\end{array}$} & Aggressive & 21 & 0.190 & 0.238 & 0.572 & 0.310 & 0.69 & 6.628 \\
\hline & Non-aggressive & 100 & 0.420 & 0.290 & 0.290 & 0.56 & 0.44 & $(P=0.036)$ \\
\hline & Total & 121 & 0.380 & 0.281 & 0.339 & 0.521 & 0.479 & \\
\hline & & & $C / C$ & $C / T$ & $T / T$ & $C$ & $T$ & \\
\hline HTR2B/TaqI & Aggressive & 21 & 0.381 & 0.381 & 0.238 & 0.571 & 0.429 & 0.026 \\
\hline \multirow[t]{2}{*}{ Exon I } & Non-aggressive & 100 & 0.370 & 0.400 & 0.230 & 0.570 & 0.430 & $(P=0.98)$ \\
\hline & Total & 121 & 0.372 & 0.397 & 0.231 & 0.570 & 0.430 & \\
\hline
\end{tabular}

$\mathrm{n}$ - number of individuals, $\chi^{2}-$ chi-square test 
frequencies are shown in Table 3 . The $H T R 2 B$ genotype and allele frequencies were almost identical in both groups and are presented in Table 3.

\section{Discussion}

In this study, two polymorphisms were investigated in groups of 21 aggressive and 100 non-aggressive dogs. The first polymorphism was based on $17 \mathrm{bp}$ repeat in intron II of dopamine receptor $\mathrm{D} 4$ gene and the second one was based on C/T substitution in exon I of 5-hydroxytryptamine receptor $2 \mathrm{~B}$ gene. Our study presents one of the first approaches of determining the relationship of the above mentioned polymorphism and aggressive behaviour in dogs.

The $D R D 4$ gene polymorphism was previously investigated in many organisms such as: primates (Livak et al. 1995), horse (Fan et al. 2011), and dog (Niimi et al. 1999; Hejjas et al. 2009). Furthermore, Hejjas et al. (2007, 2009) indicated a correlation between variability of the abovementioned gene and personality traits in dogs. Also $H T R 2 B$ gene polymorphism was analyzed for the purpose of establishing whether it is linked to behavioural traits. A study on Finnish human populations indicated that HTR2B gene variability predisposes to severe impulsivity (Bevilacqua et al. 2010). So, it is reasonable to perform further studies on polymorphism of both HTR $2 B$ and DRD 4 genes and its influence on personality traits, especially the tendency to aggression.

Our study was the first where $\mathrm{C} / \mathrm{T}$ substitution in exon I HTR $2 B$ was analyzed in a group of dogs. The following genotypes were observed: homozygotes $C / C$, heterozygotes $C / T$ and homozygotes $T / T$. There was no predominant genotype in both groups of dogs (aggressive and non-aggressive). The minor allele was $T$ and its frequency was almost the same in both groups ( $\mathrm{f}=0.430$ in non-aggressive dogs and $\mathrm{f}=0.429$ in aggressive $\operatorname{dogs}$ ). There was no significant difference of genotype distribution between the analyzed groups of animals $(P=0.98)$.

Previous studies on DRD4 intron II VNTR polymorphism were made by Nara et al. (2005) and Hejjas et al. (2009). Nara et al. (2005) divided dogs in two groups depending on their breed (oriental and occidental). The results of genotyping were extremely different for these groups. In the group of dogs of oriental breeds, $P$ was the minor allele $(\mathrm{f}=0.152)$, whereas in the other group, $P$ was the predominant allele $(\mathrm{f}=0.616)$. In this study frequency of $P$ allele was 0.479 . Hejjas et al. (2009) indicated that the region in DRD4 intron II, where this polymorphism is located, showed a significant transcriptional activity. On the basis of this observation, they concluded that the mentioned region can play a role as an alternative promoter. The study performed by Hejjas et al. (2009) included genotype distribution analysis in five dog breeds and in the European grey wolf. The $P / P$ genotype was the most frequent in the German shepherd $(f=0.483)$ and the least frequent in the Siberian husky ( $\mathrm{f}=0.03$ ). The frequency of heterozygotes was the highest in the Belgian malinois $(0.520)$ and the lowest in the Siberian husky $(f=0.051)$. The $Q / Q$ homozygotes were the most frequent in the Siberian husky $(f=0.911)$ and the least frequent in the German shepherd $(f=0.124)$. All wolves were $P / P$ homozygotes. Their study indicated an association between DRD4 intron II polymorphism and social impulsivity in German shepherds. Our study indicated a significant difference in genotype distribution between the groups of aggressive and non-aggressive dogs $(P=0.036)$. Nevertheless, it is known that DRD4 allele frequencies differ among breeds (Hejjas et al. 2007). Thus our results could be affected by the presence of unequal numbers of dogs of different breeds within the investigated groups.

Aggressive behaviour is very complicated and the basis of its occurrence has not been well explained yet. It is thought that the tendency to aggressiveness is an effect of both environmental and genetic factors (Våge et al. 2010). Aggression is a very undesirable 
behaviour, especially in animals accompanying humans such as dogs. Our study has contributed to acquiring information on its genetic background which could be crucial for achieving the goal of reducing the aggression occurrence in dogs.

\section{References}

Barsky PI 2010: Environment, genes, and experience: Lessons from behavior genetics. J Psychol 104: 243-252

Bevilacqua L, Doly S, Kaprio J, Yuan Q, Tikkanen, Paunio T, Zhou, Wedenoja J, Maroteaux L, Diaz S, Belmer A, Hodgkinson CA, Dell'Osso L, Suvisaari J, Coccaro E, Rose RJ, Peltonen L, Virkkunen M, Goldman D 2009: A population-specific HTR2B stop codon predisposes to severe impulsivity. Nature 468: 1061-1068

Bradley PB, Engle G, Feniuk W, Fozard JR, Humphrey PPA, Middlemis DN, Mylecharane EJ, Richardson BP, Saxena PR 1986: Proposals for the classification and nomenclature of functional receptors of 5-hydroxytryptamine. Neuropharmacology 25: 563-576

Fan C, Cheng J, Li J, Wang Q, Manglai D 2011: Polymorphism analysis of the horse dopamine receptor D4 gene (DRD4) sequence. J Anim Vet Adv 10: 1855-1858

Fitzgerald P 1999: Long-acting antipsychotic medication, restraint and treatment in management of acute psychosis. Aust NZ J Psychiat 33: 660-666

Hart BL, Miller MF 1985: Behavioral profiles of dog breeds. J Am Vet Med Assoc 186: 1175-1180

Hejjas K, Kubinyi E, Ronai Z, Szekely A, Vas J, Miklósi Á, Sasvari-Szekely M, Kereszturi E 2009: Molecular and behavioral analysis of the intron 2 repeat polymorphism in the canine dopamine D4 receptor gene. Genes Brain Behav 8: 330-336

Hejjas K, Vas J, Topal J, Szantai E, Ronai Z, Szekely A, Kubinyi E, Horwath Z, Sasvari-Szekely M, Miklósi Á 2007: Association of polymorphism in the dopamine D4 receptor gene and the activity-impulsivity endophenotype in dogs. Anim Genet 38: 629-633

Houpt KA 2007: Genetics of canine behavior. Acta Vet Brno 76: 431-444

Livak KJ, Rogers J, Lichter JB 1995: Variability of dopamine D4 receptor (DRD4) gene sequence within and among nonhuman primate species. Proc Natl Acad Sci 92: 427-431

Nara H, Inoue-Murayama M, Koshimura A, Sugiyama A, Murayama Y, Maejima M, Ueda Y, Ito H, Randi E, Kim HS, Ha JH, Kitagawa H, Takeuchi Y, Mori Y, Iwasaki T, Morita M, Ota K, Ito S 2005: Novel polymorphism of the canine dopamine receptor D4 gene intron II region. Animal Sci J 76: 81-86

Nelson RJ, Chiavegatto S 2001: Molecular basis of aggression. Trends Neurosci 24: 713-719

Niimi Y, Inoue-Murayama M, Murayama Y, Ito S, Iwasaki T 1999: Allelic variation of the dopamine receptor polymorphic region in two dog breeds, Golden Retriever and Shiba. J Vet Med Sci 61: 1281-1286

Picciotto MR, Wickman K 1998: Using knockout and transgenic mice to study neurophysiology and behavior. Physiol Rev 78: 1131-1163

Savitz JB, Ramesar RS 2004: Genetic variants implicated in personality: A review of the more promising candidates. Am J Med Genet B 131B: 20-32

Summers CH, Winberg S 2006: Interactions between the neural regulation of stress and aggression. J Exp Biol 209: $4581-4589$

Untergasser A, Nijveen H, Rao X, Bisseling T, Geurts R, Leunissen JA 2007: Primer3Plus, an enhanced web interface to Primer3. Nucleic Acids Res 35: 71-74

Våge J, Ligas F 2008: Single nucleotide polymorphisms (SNPs) in coding regions of canine dopamine- and serotonin-related genes. BMC Genet 9 (Accessed on: http://www.biomedcentral.com/1471-2156/9/10)

Våge J, Bønsdorff TB, Arnet E, Tverdal A, Lingaas F 2010: Differential gene expression in brain tissues of aggressive and non-aggressive dogs. BMC Vet Res 6: 34 
Plate V

Proskura S. et al.: Genetic ... pp. 441-445

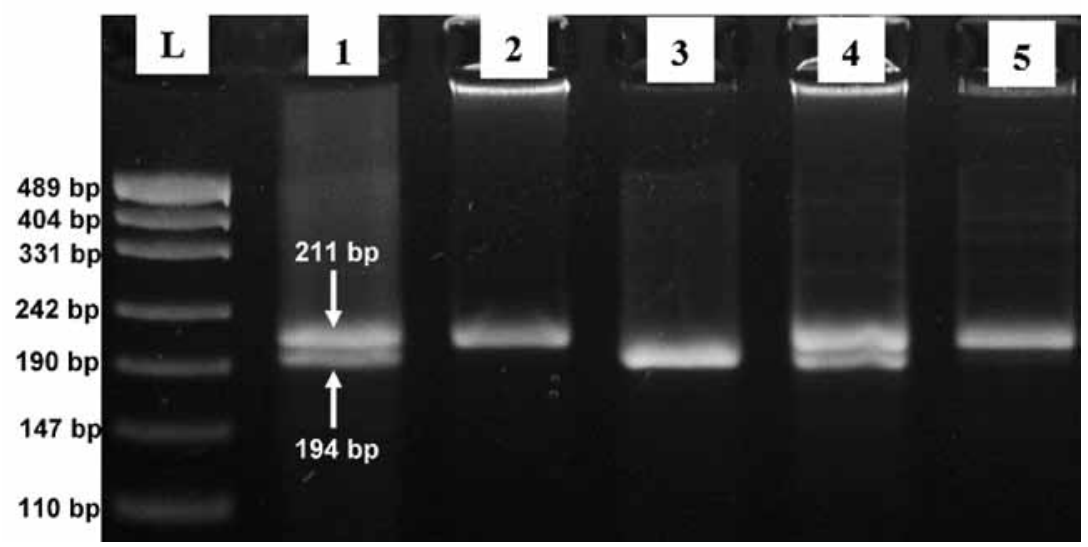

Fig. 1. Genotyping of $17 \mathrm{bp} \mathrm{VNTR} \mathrm{polymorphism} \mathrm{in} \mathrm{intron} \mathrm{II} \mathrm{of} \mathrm{dopamine} \mathrm{receptor} \mathrm{D4} \mathrm{gene} \mathrm{in} \mathrm{dogs}$ L - DNA ladder pUC19 DNA/MspI; 1,4 - $P / Q$ genotype; $2,5-Q / Q$ genotype; $3-P / P$ genotype

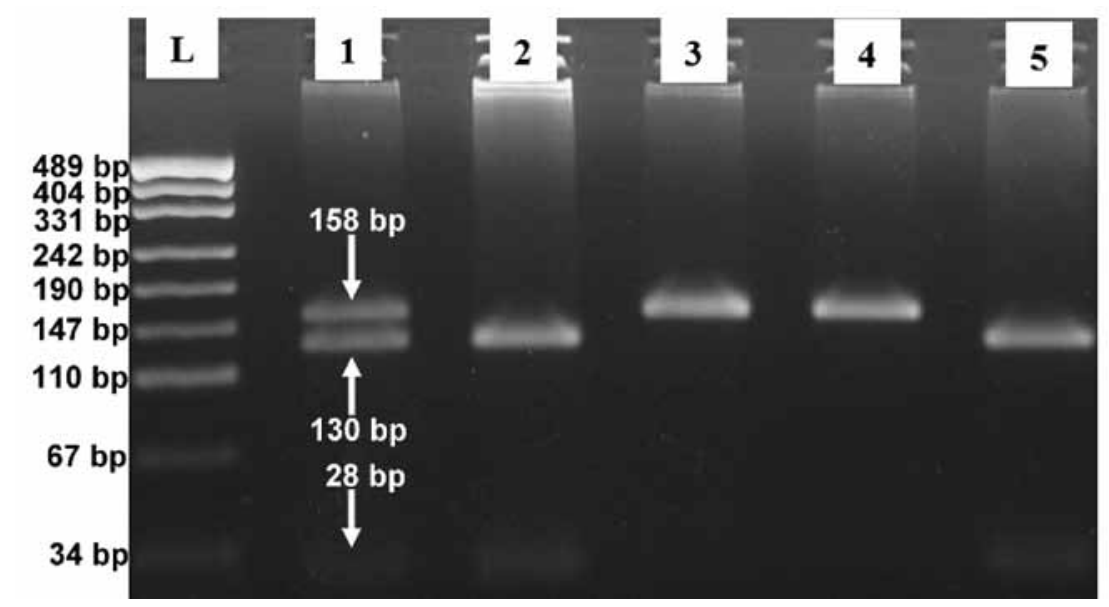

Fig. 2. Genotyping of $\mathrm{C} / \mathrm{T}$ substitution in exon $\mathrm{I}$ of serotonin receptor $2 \mathrm{~B}$ gene in dogs L - DNA ladder pUC19 DNA/MspI; $1-C / T$ genotype; 2, $5-T / T$ genotype; $3,4-C / C$ genotype 